\title{
Analysis of the Dimension of the Quality of Service with Online Registration System Again to Increase Patient Satisfaction in Outpatient Room of Jombang General Hospital
}

\begin{abstract}
Email:
nasrulloh99n9@gmail.com

\author{
Masrulloh', Sentot Imam², \\ ${ }^{1}$ Magister of Health Study \\ Kesehatan STRADA Indonesia \\ ${ }^{2}$ Lecturer of Institut Ilmu \\ Yuly Peristiowati
Yulon
}

\begin{abstract}
Granting of services on patients the best should give fast service, so that patients are not left waiting a long time to get good, turn at the time of registration or get a room and also at the time of payment. Customers come to your place of service by the time that random, irregular and cannot immediately be served so they have to wait in a long time. In studying the theory of queues, service providers are able to cultivate in order to serve its customers well without having to wait for a long time. The purpose of this research was to analyze the effect of the dimensions of the quality of service with online registration system with increased Patient satisfaction In Outpatient Room of Jombang General Hospital. Design of this research are analytic observational design with a quantitative approach. Variable Dimension, namely the quality of service research online registration (Accuracy, readiness, Speed response) as the independent variable. Patient satisfaction as the dependent variable. The population of this research the whole of patient at Outpatient Room of Jombang General Hospital. as much as 625 patients. Samples taken with the cluster random sampling technique as much as 125 respondents. Data is collected with instruments ceklist and processed in coding, editing, tabulating and scoring as well as tested with linear regression test. Linear regression results indicate that partially and simultaneously the value of $p$ values there are shows $<0,05$ so that thereis influence the dimensions of quality of service with online registration system with increased Patient satisfaction In Outpatient Room of Jombang General Hospital. The existence of the speed of service, timeliness of service and readiness the implementation of online registration will affect patient satisfaction. Because the patient will feel comfortable with fast service and not too long to wait, and also with the proper services are provided in accordance with the complaint and adequate facilities.
\end{abstract}

Keywords: Dimentions of quality service, saisfaction, online registration system
Received: October 12, 2019
Accepted : February 13, 2020

Published: May 10, 2020

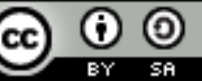

This is an open-acces article distributed under the terms of the Creative Commons Attribution-ShareAlike 4.0 International License. 


\section{INTRODUCTION}

One of the things that is very important in realizing customer satisfaction service quality is given a health service instance. In an era of very tight competition this hospital is expected to have an awareness of the importance of providing the best quality service for its customers. Jombang public hospital is a government hospital that continues to strive to be able to provide excellent service and quality in the middle of the rivalry of the Hospital today, but last year there was a decline in the number of visits the patient, this could due to the dissatisfaction felt by the patient over a given service.

Rahayu (2013) are one of the events that usually occurs frequently in a hospital is the State where patients queue up in the registration of inpatient care, get the room for inpatient as well as payment after the completion of inpatient treatment. In providing the best service should give fast service, so that customers are not left waiting a long time to get good, turn at the time of registration or get a room and also at the time of payment. Customers come to your place of service by the time that random, irregular and cannot immediately be served so they have to wait in a long time. In studying the theory of queues, service providers are able to cultivate in order to serve its customers well without having to wait for a long time.

Improved quality of health care is very important to do by health care providers such as hospitals in order to improve patient satisfaction. An increase in patient satisfaction is the main goal of becoming a health institution, because the patient is satisfied with will affect the perception of patients against hospitals and patients can recount his experiences to others so that interest of the person to perform repeated visits a medical examination at a hospital or other health care services (Kitapci, 2014). Patient registration site is the first service as the gateway has a very important role in giving the first impression for the patient as a consumer (Wahyuningsih, 2009 in goddess, 2015). Patient waiting time in Ministry in place of registration is one of the important things that will determine the image of the beginning of the hospital. Waiting time of patients is one of the components of a potential cause of dissatisfaction. Patients will assume a ugly health services if the pain does not heal, queued, and health workers are not friendly even though professional. When the waiting time in outpatient medical record long then it will reduce the comfort of patients and the effect on the image of the hospital that can affect the patient's utility in the future (Febriyanti, 2013).

According to Kotler (2012) mentions five dimensions of service quality that must be met that is tangible, empathy, reliability, responsiveness, assurance. According to Suradi (2011) model of comprehensive satisfaction with primary focus on service of goods and services includes five dimensions of assessment, namely ketanggapan (responsiveness), reliability (reliability), guarantees (assurance), empathy (emphaty), direct evidence (tangible). Patient satisfaction is affecting consumers to tell their experience to prospective consumers or consumers. This action occurs because consumers feel at ease in obtaining the service, easy-to-access services and patients feel trust and honor in receiving the service (Semovitz, 2012).

Patient adherence to quality service and effective is if his service is convenient, fun, and friendly, where its staff members as a whole gives the impression of satisfaction towards the patient. While the Ministry explain the giver of good quality and efficient services if his Ministry in accordance with government standards. As for the conditions that often complained of by the service users of the hospital are: the attitude and actions of the doctor or nurse, the attitude of the Administration Officer, the inadequate means, the sluggish service, supplies of drugs, the rate of service, medical equipment and others ( Azwar 1996 in Chairunnisa, 2017). According to Azwar (2010), quality health care is a health service that can satisfy any service users of the services in accordance with the average level of satisfaction of the population as well as its compliance with the standard and code of ethics of the profession that has been established. Kotler (2010), in his book "marketing management" says that the satisfaction 
(satisfaction) is feeling happy or disappointed someone arising because of the perceived performance comparing products or results against the expectations of users of the service ( of the consumers). Customer satisfaction becomes a destination for companies engaged in health services such as hospitals in order to retain customers and stimulate the emergence of interest refer to the public.

Patient satisfaction is a major factor and was benchmark of success as a result of service provided to the customer in this case patients have an impact against an increase in the number of visits the patient, and the patient is satisfied will be back using the service. A good understanding of each officer's satisfaction about the hospitals the patients so that the clerk will give you the best service and give a decision against a patient (Mayasari, 2016). Improved quality of service, will effect positively to productivity, so the effort like this hospital its existence will be increasingly felt in society. To address the above, then the management of the Jombang General Hospitals take steps based on a vision of a hospital that is becoming a superior Trusted Hospitals and Islamic. The hospital's efforts to realize that vision must always improve service quality by improving the quality and quantity of human resources, complement and infrastructure as well as conducting maintenance and repair support smooth service to patients (Kurniawan, 2016). Jombang public hospital is one of the Government hospitals in Ticino has developed a variety of on-site services and good health as well as the public, specialist examination of supporting others. But based on data obtained at the outpatient in the year 2015 as much 36,610 hanggang 36,197 in 2016. The above observations indicate that although the number of visits relative increase every month but the number of visits per year has decreased. This happens due to the given service shows service less than optimal, especially judging from the speed of service at patient registration system so that this affects patient satisfaction.

\section{METHODS}

Design of this research are analytic observational design with a quantitative approach. Variable Dimension, namely the quality of service research online registration (Accuracy, readiness, Speed response) as the independent variable. Patient satisfaction as the dependent variable. The population of this research the whole of patient at Outpatient Room of Jombang General Hospital. as much as 625 patients. Samples taken with the cluster random sampling technique as much as 125 respondents. Data is collected with instruments ceklist and processed in coding, editing, tabulating and scoring as well as tested with linear regression test.Implementation began in September - November 2018. As for the assessment of each of these variables can be explained in the following way:

1) Speed

a. Quick $<60$ minutes

b. Slow $>60$ minutes

2) Accuracy

a. If done according to the indications and procedures

b. Less Appropriate if there are actions that are not done in accordance with the indications and procedures

3) Readiness

Classification of Readiness is calculated using univariate analysis according to the formula Arikunto (2010) as follows:

$\mathrm{P}=\mathrm{F} / \mathrm{N} \times 100 \%$

Keterangan : $\quad \mathrm{P}=$ Prosentase of Categorys

$\mathrm{F}=$ Frekuention of Categorys

$\mathrm{N}=$ Amount Of respondent

According to the Interview And the Goddess (2011) as follows:

a) Good = when score $76-100 \%$

b) Enough $=$ if the score $56-75 \%$

c) Less $=$ good if the score $56<\%$

4) Assessment of customer satisfaction

Patient satisfaction rated based on customer satisfaction indicators, namely:

a) Tangible 
b) Reability

c) Responsivenes

d) Assurance

e) Empathy

The fifth of these indicators was formed in a questionnaire with likert scale with the use of assessment results of filling questionnaire using the following formula:

$\mathrm{P}=\frac{f}{n} \times 100 \%$

Keterangan :

$\mathrm{P}$ : Satisfaction Value

$f$ : Amount Of Score

$\mathrm{n}$ : maksimal Score

Next the percentage of answers are interpreted in a sentence according to the qualitative statement of Wawan (2010) in the following way:
a) Satisfied: $76-100 \%$
b) Quite satisfied: $56-75 \%$
c) Less Satisfied : $<56 \%$

5) Analisis Bivariat dan Multivariat

To find out whether or not there is a relationship between variables used Test Spearman Rho because of the scale of ordinal data used and to perform multivariate test researchers using Linear regression test

\section{RESULT}

1. Partial analysis

Tabel 1 Liner regersi analysis of partially (test $t$ test) between independent variables (preparedness, speed and accuracy) and the dependent variable (satisfaction of the patient) at the Jombang general Hospitals in November $(n=125)$

\begin{tabular}{llcc}
\hline \multicolumn{1}{c}{ Variabel X } & \multicolumn{1}{c}{ Variabel Y } & T test Value & P value \\
\hline Speed Service & Satisfaction & 2.932 & 0,006 \\
\hline Accuracy Of Service & Satisfaction & 3.999 & 0,004 \\
\hline Readyness for Online Registration & Satisfaction & 4.651 & 0,000 \\
\hline
\end{tabular}

Based on the results in table 1 shows that the whole dimension of the quality of service (speed, accuracy, and the readiness of the registration) affect the satisfaction shown by all values of $P$ value $<0.05$ so that partially variable independent affect the dependent variable.

2. Simultaneously Analysis

Tabel 2 Multivariate Analysis simultaneously or synchronously between independent variables (preparedness, speed and accuracy) and the dependent variable (satisfaction of the patient) at the Jombang General Hospitals in November $(n=125)$

\begin{tabular}{llrrrrr}
\multicolumn{7}{c}{ ANOVA $^{\mathbf{a}}$} \\
\hline Model & & Sum of Squares & \multicolumn{1}{c}{ df } & Mean Square & F & \multicolumn{1}{c}{ Sig. } \\
\hline 1 & Regression & 11794.541 & 3 & 3931.514 & 18.508 & $.000^{\mathrm{b}}$ \\
& Residual & 25703.491 & 121 & 212.426 & & \\
& Total & 37498.032 & 124 & & & \\
\hline
\end{tabular}

a. Dependent Variable: Satisfaction

b. Predictors: (Constant), Speed OF Service, Accuracy Of Service Readiyness OF Online Registration

Based on the results in table 2 shows that all the dimensions on the quality of service (speed, accuracy, and the readiness of the registration) together can affect the patient's satisfaction with the value of significance can be expressed $<0.05$ so that simultaneously or synchronously dimensions on quality of service (speed, accuracy, and the readiness of the registration) can affect patient satisfaction 


\section{DISCUSSION}

A. Speed of service system to enrol online at Outpatient Instalation at Jombang General Hospitals

Based on the speed of service at outpatient Instalation At Jombang General Hospitals most patients declare fast as much as 67 respondents (53.6\%) and a fraction slow as much as 58 respondents stated $(46.4 \%)$

Quality of service is the goal of an agency or institution. The quality or the quality of service provided through a good management approach into the main requirement that should not be overlooked if a service provider wants to stay can be developed and developing, the increasingly tight competition nowadays makes an institution service provider or the service seeks to be able to provide a service or services to consumers with service excellence and best (Assauri, 2013). Patients will assume a ugly health services if the pain does not heal, queued, and health workers are not friendly even though professional. When the waiting time in outpatient medical record long then it will reduce the comfort of patients and the effect on the image of the hospital that can affect the patient's utility in the future (Febriyanti, 2013).

The results of this study indicate that service of process is given in the outpatient Instalation At Jombang General Hospitals included in good service where it can be seen from the response of a given service is already fast enough. This can be seen on the speed of the response given by the registration officers in calling the patient although had to wait or queue up but the waiting time is not too long, and laboratory examination or inspection process support done with quickly enough so that the patient can immediately know the circumstances or health disorders. Speed of response services provided outpatient Instalation At Jombang General Hospitals make respondents feel comfortable in receiving health care in government hospitals.

\section{B. Accuracy of service system to enrol online at Outpatient Instalation at Jombang General Hospitals}

Based on the accuracy of the data shows that the Ministry almost entirely respondents said services provided in Outpatient Poly officer exactly as much as 95 respondents $(76 \%)$ and the fraction stating less precise 30 respondents (24\%).

According to Zethaml, 2006 In Surydna (2017) States that service quality is an important element in receiving the response service provider customers such as hospitals, financial institutions, and educational institutions. If the service received exceeds customer expectations expectations then the Ministry is said to be good. If the service provided in accordance with the expectations of the customers eat the service quality is said to be ideal. And if the service provided is less meet the expectations of customers then the bad quality of service.

The results of this study indicate that service of process is given in the outpatient Instalation At Jombang General Hospitals is already fast enough and the service provided has also been quite right. This can be seen on the precision of the officer in giving the patient medical record, accuracy checks carried out by officers of good examination dokte examination as well as supporting ratau act committed by nurses can be said quite right Although sometimes there are nurses who are less friendly toward the patient and less nimble in responding to the complaints of the patient. The accuracy of the services provided by the clerk in outpatient Instalation At Jombang General Hospitals make respondents feel comfortable and secure enough in conducting health checks or receive other medical services in the hospital.

C. Readiness of system to enrol online at Outpatient Instalation at Jombang General Hospitals Based on the readiness of the Officer in online registration system showed that most of the patients stated clerk is enough ready in doing Ministry online to enrol as many as 72 respondents $(57.6 \%)$ and a small part of the States are less prepared in implement online registration system as much as 53 respondents $(42.4 \%)$.

Quality of service is the goal of an agency or institution. The quality or the quality of service provided through a good management approach into the main requirement that should not be overlooked if a service provider wants to stay can be developed and developing, the increasingly 
tight competition nowadays makes an institution service provider or the service seeks to be able to provide a service or services to consumers with service excellence and best (Assauri, 2013). Multiple dimensions of quality that must be observed by service providers, namely; timeliness of service, service accuracy, politeness and hospitality services, liability, completeness, ease, variation model of service, personal service, comfort get the services and other services (supporting attributes Bustami, 2012).

The results of this research show that the online registration system conducted by the outpatient Instalation At Jombang General Hospitalscan be said officers executing is enough ready in applying that system. This can be seen in the place of registration and the available equipment in good condition to do logging and psien registration so that simplify patient in exercising and receive services at outpatient Instalation At Jombang General Hospitals, besides officers also always on hand or standby registration in a room in order to provide better services on patients, although sometimes the officer must turn in receiving the registration because there are officers who are also tasked to conduct election record record and deliver medic medic patients. Readiness officer in carrying out online registration system can already be said quite ready.

\section{Patient Satisfaction of outpatient Instalation At Jombang General Hospitals}

Based on the characteristics of patient satisfaction data obtained almost half of patients feel quite satisfied with the service received as many as 58 respondents (46.4\%).

The results of this research are supported with research Ghourab Adhikary (2017) of factorfactors that affect patient satisfaction various types of hospitals in Bangladesh who showed 63.2\% of patients were satisfied with the service provided, which consists of 73 percent at private hospital patients and 27 percent of patients government hospitals.

Customer satisfaction is the goal of the entire business activity and is the most accessible promotional suggestions do (Kitapci, 2014). Consumer satisfaction is defensive and offensive strategy, that is to say as a defensive strategy because customer satisfaction is the best way to restrain consumers from competitors and as a description of the offensive strategy because customer satisfaction will lead to Word of march and able to attract new consumers (Supriyanto,2010).

The results of this study indicate that many patients feel satisfied on Ministry received mainly on the skills of the officers and the response provided in responding to the complaints of the patient, in addition officers are also friendly to the patient so patients feel comfortable in receiving services provided by the officer. According to the clerk at the poly patients Outpatient is quite clear and easy to understand in giving information on the patients and they did not wait for the menginggatkan time to do patient visits and drug-taking. In addition the patient felt the officers take better care of patients for example they always invite the patient speak when giving therapy so that susaana becomes not the tense and administering the therapy to be smooth. Whereas in patients who feel less happens because still there are some nurses who are less friendly, and when giving therapy they look stiff and response provided appears still a long time.

E. The influence of dimensions of the quality of service to the satisfaction of the patients in outpatient Instalation At Jombang General Hospitals

Based on the results in partial dimensions that the quality of service (speed, accuracy, and the readiness of the registration) affect the satisfaction shown by all values of $\mathrm{P}$ value $<0.05$ so that partially variable independent affect the dependent variable. Based on the results of simultaneous shows that all dimensions on quality of service (speed, accuracy, and the readiness of the registration) together can affect the patient's satisfaction with the value of significance can be expressed $<0.05$ so that simultaneously or synchronously dimensions on quality of service (speed, accuracy, and the readiness of the registration) can affect patient satisfaction.

The results of the study supported the research of the research Nurjannah (2017) that showed the highest frequency to the time registration was $49 \%$ fast, $81 \%$ waiting time speed is very fast, the speed of time OD (Oral Diagnosis) 68\% very quickly and speed of treatment of $42 \%$ currently. The level of satisfaction of patients obtained $71 \%$ of the respondents feel satisfied. Spearman 
correlation test results indicate that there is a relationship between speed of service to the patient's satisfaction in Jember University RSGM.

Quality of service is very important in realizing customer satisfaction. In an environment that is increasingly full of competition, especially health services agency Clinics which is the first Ministry of health problems in the community against must be increasingly aware of the importance of providing quality the best services for its customers. The increase in the health service is very important to be made by health care provider institutions such as clinics in order to improve patient satisfaction. Patient satisfaction is the level of one's feelings after comparing the performance of the patient experience with the hope that patients want when intending to seek treatment. If the patient feels satisfied, this greatly affect an action based on the past experiences where they won't be easy to switch services because the stimulation of marketing (Yulfita, 2016). Improved quality of health care is very important to do by health care providers such as hospitals in order to improve patient satisfaction. An increase in patient satisfaction is the main goal of becoming a health institution, because the patient is satisfied with will affect the perception of patients against hospitals and patients can recount his experiences to others so that interest of the person to perform repeated visits a medical examination at a hospital or other health care services (Kitapci, 2014). Patient registration site is the first service as the gateway has a very important role in giving the first impression for the patient as a consumer (Wahyuningsih, 2009 in goddess, 2015). The results of this research show that the dimension of the quality of service in the implementation of online registration system conducted polirawat the way HOSPITALS Jombang affect the satisfaction felt by the patient. The existence of the speed of service, timeliness of service and readiness the implementation of online registration will affect patient satisfaction. Because the patient will feel comfortable with fast service and not too long to wait, and also with the proper services are provided in accordance with the complaints and needs of the patient and the patient see peratalan or adequate facilities and complete and officers who provide ready and friendly and skilled. Satisfaction is received by these patients will give a positive impact on hospitals which were penignkatan the number of visits the patient because of the new and old patients are satisfied it is not impossible they will recount the experience received to another person so that the person is interested to make a visit to the hospital. This indicates that the dimension of the quality of service of hospital terkati online registration system (speed of service, timeliness of service and readiness of the online registration system) influence on patient satisfaction.

\section{CONCLUTION}

1. The dimension of the quality of service in the online registration system shows the data based on the speed of service in outpatient Instalation At Jombang General Hospitals most patients declare fast as much as 67 respondents (53.6\%). Based on the accuracy of the data shows that the Ministry almost entirely respondents said services provided in Outpatient Poly officer exactly as much as 95 respondents $(76 \%)$. Based on the readiness of the Officer in online registration system showed that most of the patients stated clerk is enough ready in doing Ministry online to enrol as many as 72 respondents $(57.6 \%)$.

2. Patient Satisfaction in outpatient Instalation At Jombang General Hospitalsdata obtained nearly half the patients feel quite satisfied with the service received as many as 58 respondents (46.4\%)

3. There is the influence of dimensions of service quality related Quality system registration online against the satisfaction of patients in outpatient Instalation At Jombang General Hospitals, indicated by the value of the $\mathrm{p}$ value on a partial test and synchronously $<0.05$.

\section{REFERENCE}

Arikunto, Suharsini. 2010. Prosedur Penelitian: Suatu Pendekatan Praktek. Jakarta: Rineka Cipta.

Bustami. 2012. Penjaminan Mutu Pelayanan Kesehatan \& Akseptabilitasnya. Jakarta: Erlangga.

Chairunnisa. 2017. Gambaran Kepuasan Pasien Rawat Jalan terhadapPelayanan di Rumah Sakit Islam JakartaSukapura (RSIJS. Jurnal Kedokteran dan Kesehatan, Vol.13, No. 1, Januari 2017 
Dewi Aulia Utami. 2015. Hubungan Waktu Tunggu Pendaftaran DenganKepuasan Pasien Di Tempat Pendaftaran Pasien RawatJalan (TPPRJ) RSUD Sukoharjo. Artikel Ilmiah Fakultas Ilmu Kesehatan Universitas Muhammadiyah Surakarta

Donsu, Jenita Doli Tine. 2016. Metodologi Penelitian. Yogyakarta : Pustaka Baru Press

Fauzan Muhammad. 2017. Studi Tentang Sistem Informasi PendaftaranRujukan Rawat Jalan Online (Sipulan)Di RSUD A.M Parikesit Tenggarong. eJournal Administrative Reform, Volume 5, Nomor 3, 2017: 622-632

Febriaynati. 2013. Analisis Pengaruh KualitasPelayanan Terhadap Kepuasan Konsumen. Artikel Ilmiah Fakultas Ekonomi Dan Bisnis Universitas Diponegoro Semarang

Ghaurab Adikary, et all. 2017. Factors Influencing Patients' Satisfaction AtDifferent Levels Of Health Facilities InBangladesh: Results From Patient ExitInterviews. Plosone Journal athttps://doi.org/10.1371/journal.pone.0196643

Ghozali, Imam. 2011.Aplikasi Analisis Multivariate. Badan Penerbit Universitas Diponegoro. Semarang

Khamasi and Njau. 2014. Patients' level of satisfaction on quality of health care at Mwananyamala hospital in Dar es Salaam,Tanzania.BMCHealth Services Research $2014,14: 400$

Kitapci, Olgun. 2014. The Impact of Service Quality Dimensions on Patient Satisfaction, Repurchase Intentions and Word-of-Mouth Communication in the Public Healthcare Industry. Elsevier, Procedia - Social and Behavioral Sciences. Vol. 148, 161 - 169

Kotler, Philip \&Kevin Lane Keller. 2012.MarketingManagement,14th Edition. New Jersey:Pearson Education,Inc (Publishingas PrenticeHall).

Kotler,PhilipdanArmstrong,Gary.2012. Principles of Marketing (Fourteenth Edition). England: Pearson Education Limited

Krishna Naik. 2013. A Conceptual Analysis of service Quality in Tourism Industry. Journal of Servive Marketing. Vol 16 (4), 36379.

Lovelock \& Lauren K Wright.2010. Manajemen Pemasaran Jasa, Jakarta : PT. Indeks, Indonesia

Lupiyoadi, Rambat. 2013.Manajemen Pemasaran JasaBerbasis Kompetenis.Jakarta:Salemba Empat

Mayasari, Fitriyuli. 2016. Analisis Hubungan Waktu Pelayanan dan Faktor Total Quality ServiceTerhadap Kepuasan Pasien di Poliklinik Kebidanan dan Kandungan RSIAAnugerah Medical Centre Kota Metro Tahun 2015. Jurnal Administrasi Rumah Sakit Volume 2 Nomer 3

Muninjaya,A.A Gde. 2015.Manajemen Mutu Pelayanan Kesehatan,edisi II. Jakarta : EGC

Nurjannah Alifah, 2017. Hubungan Kecepatan Waktu Pelayanan terhadap KepuasanPasien di Rumah Sakit Gigi dan Mulut Universitas Jember (The Relation of Speed Time Service to Patient Satisfaction in Rumah Sakit Gigi dan Mulut Universitas Jember). e-Jurnal Pustaka Kesehatan, vol. 5 (no. 1), Januari 2017

Nkrumah, Seth.2015. Client Satisfaction with Service Delivery in the Health Sector: The Caseof Agogo Presbyterian Hospital. International Journal of Business Administration. Vol. 6, No. 4. 
Panda Prem S. 2018. Level of satisfaction of patients attending out-patieradiotherapy department of a tertiary hosRaipur, Chhattisgarh, India. International Journal of Research in Medical Sciences. www.msjonline.org

Sugiyono. 2015. Metode Penelitian Kuantitatif, Kualitatif Dan $R \&$ D.Cetakan ke-24. Bandung : Alfabeta.

Suradi, 2011. Pengaruh produksi, Faktor sosial, Harga, Iklan, dan Word of mouth terhadap keputusan pembelian Sony Xperia pada mahasiwa Universitas Sumatera Utara.

Surydana, Liga.2017. Service Quality, Customer Value and Patient Satisfaction on Public Hospital in Bandung District, Indonesia. Econ Journals, International Review of Management and MarketingVolume 7 No. 2, 187-192.

Tjiptono,Fandy. 2014. Pemasaran Jasa. Malang:Bayumedia Publishing

Yohana, Antin. 2012. Analisis Harapan dan Kepuasan Paien Rawat Inap Penyakit Dalam terhadap Mutu Pelayanan Dokter Spesialis di RSI Sunan Kudus. Tesis Tidak Dipublikasikan. Semarang: Universitas Diponegoro 